REVISTA DE DERECHO UNED, NÚM. 12, 2013

\title{
REFLEXIONES SOBRE LA LIBERTAD DE TESTAR Y LA STEDH DE 13 DE JULIO DE 2004
}

\author{
THINK ABOUT THE FREEDOM OF TESTAMENTARY \\ DISPOSITION AND THE ECHR JUDGMENT OF 13 JULY 2004
}

Fernando Carol Rosés

Abogado. Doctorando del Departamento de Derecho civil de la UNED

Resumen: La STEDH de 13 de julio de 2004 -dictada en un litigio que tiene su origen en una demanda presentada contra el Principado de Andorra- elude abordar de forma directa el hipotético conflicto entre libertad de testar y principio de igualdad y,en cambio, reelabora la voluntad del testador a la luz del Convenio Europeo de Derechos Humanos, lo cual supone un ataque a la esencia misma de la sucesión testada. Aunque con carácter de obiter dicta entiende que cualquier relación jurídica de Derecho privado deberá ser interpretada de conformidad con el Convenio, afirmación que cuestiona la propia autonomía privada. Si bien en España, como en otros muchos Estados miembros del Consejo de Europa, las sentencias del Tribunal Europeo de Derechos Humanos no son directamente ejecutivas, sí es cierto que a la luz del artículo 10.2 de la Constitución Española tanto el principio de igualdad como los demás derechos fundamentales y libertades deberán ser interpretados de conformidad con los acuerdos internacionales ratificados por España, siendo ésta precisamente la vía que conduce a la efectividad de la jurisprudencia del Tribunal Europeo de Derechos Humanos, creando, en el caso que nos ocupa, una situación, cuanto menos, preocupante.

Abstract: The ECHR Judgment of 13 July 2004 -dictated in a litigation that has his origin in a demand presented against the Principality of Andorra- eludes to approach of direct form the hypothetical conflict between freedom of testamentary disposition and beginning 
of equality, with the consequence that there re-elaborates the will of the testator in the light of the European Agreement of Human rights, which supposes an assault to the essence itself of the testate succession. Though with character of obiter dicta he understands that any juridical relation of private Law will have to be interpreted of conformity with the Agreement, affirmation that questions the own private autonomy. Though in Spain, since in other many members states of the Council of Europe, the judgments of the European Court of Human rights are not directly executive, yes it is true that in the light of the article 10.2 of the Spanish Constitution both the beginning of equality and other fundamental rights and freedoms will have to be interpreted of conformity with the international agreements ratified by Spain. Therefore, this one is precisely the route that he leads to the efficiency of the jurisprudence of the European Court of Human Rights, creating, in the case that occupies us, a situation worrying.

Palabras clave: Sucesión testada. Voluntad del testador. Libertad de testar. Tribunal Europeo de Derechos Humanos.

Key words: Testate succession. Will of the testator. Freedom of testamentary disposition. European Court of Human Rights.

Recepción original: 10/06/2013

Aceptación original: 11/06/2013

Sumario: I. Introducción; II. Los hechos; III. El Tribunal dels batlles d'Andorra; IV. El Tribunal superior de justícia d'Andorra; V. El Tribunal Constitucional d'Andorra; VI. El Tribunal Europeo de derechos humanos; 1. Argumentos de los demandantes; 2. Argumentos del Govern d'Andorra; 3. Apreciación del Tribunal y crítica de la misma; 4. Votos disidentes; 5. Efectividad interna de la sentencia; VII. Bibliografía; VIII. Índice de resoluciones judiciales citadas.

\section{INTRODUCCIÓN}

El Tribunal Europeo de Derechos Humanos (en adelante TEDH) en sentencia de 13 de julio de $2004^{1}$ dictada por la Sección Cuarta en el litigio Pla y Puncernau contra Andorra a raíz de la demanda (núm. 69498/01) presentada ante este Tribunal en fecha 16 de mayo de 2001 fundada en el artículo 34 del Convenio Europeo para la protección de los Derechos Humanos y de las Libertades Fundamen-

1 Vid., http://hudoc.echr.coe.int/sites/fra/pages/search.aspx?i=001-66458 (fecha de consulta mayo de 2013) 
tales (en adelante CEDH) ${ }^{2}$, resuelve, en una materia -el Derecho de sucesiones por causa de muerte- que no se suele ver afectada por las resoluciones de los Tribunales internacionales ${ }^{3}$, una controversia planteada como cuestión interpretativa de una cláusula testamentaria. Sin embargo, el conflicto subyacente es el que se debate entre el principio de autonomía privada del testador, por un lado, y el principio de igualdad, por otro. En estas líneas reflexionaremos no solo sobre la trascendencia de esta línea jurisprudencial en el ámbito del Derecho de sucesiones, sino en el de las relaciones jurídicas de Derecho privado, en general.

La Sección, compuesta por siete magistrados, decidió por cinco votos contra dos, con dos votos particulares (uno de Sir Nicolás Bratza, presidente, y otro de M. Garlicki). Se interpuso recurso de remisión a la Gran Sala del Tribunal convirtiéndose la sentencia en definitiva en fecha 15 de diciembre de 2004.

Por su parte, las alegaciones de los demandantes se fundaban en que se había producido con respecto del primero de ellos una discriminación, tanto por parte del Tribunal Superior de Justícia como por parte del Tribunal Constitucional, en materia de derechos sucesorios, dada su filiación. En su virtud, se había infringido el artículo $8^{4}$ considerado aisladamente y también el 145, ambos preceptos de la CEDH.

2 Como es sabido, la CEDH es un Tratado internacional adoptado en el seno del Consejo de Europa, hecho en Roma el 4 de noviembre de 1950, teniendo en consideración la Declaración Universal de Derechos Humanos proclamada por la Asamblea General de las Naciones Unidas el 10 de diciembre de 1948, con el objetivo de contribuir a una unión más estrecha entre los miembros del Consejo de Europa por medio de la protección y desarrollo de los derechos humanos y de las libertades fundamentales. Fue ratificado por el Principado de Andorra el 21 de diciembre de 1995 (BOPA núm. 83, de 22 de diciembre de 1995), entrando en vigor el 22 de enero de 1996.

3 «El TEDH se encuentra ante una problemática nueva jamás abordada anteriormente [...] el TEDH no había tenido ocasión anteriormente de pronunciarse sobre una distinción entre los hijos llamados a la sucesión realizada por el propio testador» [DAvid Bondia GARCIA en Esther Arroyo i Amayuelas y David Bondía García, "¿Intepretación del testamento contraria a los derechos humanos? "El caso 'Pla \& Puncernau vs. Andorra" (STEDH, 13 de julio de 2004)», Derecho Privado y Constitución, núm. 18, 2004, pág. 80].

4 Derecho al respeto a la vida privada y familiar. 1 . Toda persona tiene derecho al respeto de su vida privada y familiar, de su domicilio y de su correspondencia. 2. No podrá haber injerencia de la autoridad pública en el ejercicio de este derecho sino en tanto en cuanto esta injerencia esté prevista por la ley y constituya una medida que, en una sociedad democrática, sea necesaria para la seguridad nacional, la seguridad pública, el bienestar económico del país, la defensa del orden y la prevención de las infracciones penales, la protección de la salud o de la moral, o la protección de los derechos y libertades de los demás.

5 Prohibición de discriminación. El goce de los derechos y libertades reconocidos en el presente Convenio ha de ser asegurado sin distinción alguna, especialmente por 


\section{LOS HECHOS}

El 12 de octubre de 1939 Carolina Puig Oller ${ }^{6}$, de nacionalidad andorrana, otorgó testamento abierto ante notario, falleciendo en 1949 sin haberlo revocado. En el momento de su fallecimiento ya era viuda de Francesc Pla Guasch y dejaba tres hijos: Francesc-Xavier, Carolina y Sara.

En el mencionado testamento instituía heredero fiduciario a Francesc-Xavier -al cual sustituye vulgar y sucesivamente por Carolina y por Josep Antoni Serra Pla (hijo de Sara)estableciéndose una cláusula ${ }^{7}$ en la que se dice:

«El que arribi a ésser hereu haurà forçosament de transmetre l'herència a un fill o net de legítim y canònic matrimoni, al que no obstant podrà posar les condicions que cregui convenients. Y si mor sense fills o nets de legítim y canònic matrimoni passarà l'herència als fills o nets dels demés instituït o substituts en la clàusula numero vuit y amb el mateix ordre que en ella s'estableix ${ }^{8}$.

Es decir, el que llegase a ser heredero había de transmitir los bienes objeto del testamento a un hijo o a un nieto de matrimonio legítimo y canónico ${ }^{9}$ que sería el heredero fideicomisario. Y caso de fallecer sin hijos ni nietos de legítimo y canónico matrimonio pasaría la herencia a los hijos o nietos de los demás instituidos o sustitutos.

Podemos apreciar que además de una sustitución vulgar hay dos sustituciones fideicomisarias condicionales: una, si cum liberis decesserit, si el fiduciario fallecía con hijos de «legítimo y canónico

razones de sexo, raza, color, lengua, religión, opiniones políticas u otras, origen nacional o social, pertenencia a una minoría nacional, fortuna, nacimiento o cualquier otra situación.

6 El TEDH publica sus sentencias con los nombres y apellidos de los que han sido parte en el pleito.

7 Esta cláusula se transcribe tal como se reproduce en el Auto del TC andorrano de 13 de octubre de 2000 (BOPA núm. 60, año 12, 18 de octubre de 2000) (www. bopa.ad).

8 Traducción: «El que llegue a ser heredero habrá de transmitir forzosamente la herencia a un hijo o nieto de legítimo y canónico matrimonio, al cual, no obstante podrá poner las condiciones que crea convenientes. Y si muere sin hijos o nietos de legítimo y canónico matrimonio, pasará la herencia a los hijos o nietos de los demás instituidos o sustitutos en la cláusula número ocho y en el mismo orden que en ella se establece». Las traducciones tanto del francés como del catalán son mías.

9 No es lo mismo referir la legitimidad y la canonicidad al matrimonio que a los hijos. Hay hijos legítimos, no matrimonios legítimos; hay matrimonios canónicos, no hijos canónicos. Parece que en la cláusula la legitimidad se predica de los hijos y la canonicidad del matrimonio, lo cual implica una interpretación correctora. La testadora quiso referirse a los hijos legítimos de un matrimonio canónico. 
matrimonio» habría de elegir de entre ellos al fideicomisario; otra y subsidiariamente, si sine liberis decesserit, con la cual llamaba a los hijos y a los nietos de los sustitutos vulgares para el caso de que el fiduciario falleciera sin hijos de «legítimo y canónico matrimonio» ${ }^{10}$.

En la sustitución vulgar -también llamada sustitución directahay varias liberalidades y solo se ejecuta una, uno es llamado a la herencia en defecto de otro. La delación en favor del sustituto solo se produce una vez se ha frustrado la delación a favor del instituido.

Es decir, la sustitución vulgar es la disposición testamentaria en virtud de la cual el testador nombra un segundo o ulterior heredero para el caso o en previsión de que el anterior heredero instituido no llegue efectivamente a serlo, si heres non erit, por no poder (premoriencia, incapacidad, indignidad) o no querer (repudiación). En la sustitución vulgar sucesiva, como es el caso que nos ocupa, se aplica la regla substitutus substituto intelligitur substitutus instituto, que significa que cada sustituto lo es de los anteriores y directamente del instituido ${ }^{11}$.

En la sustitución fideicomisaria -llamada indirecta u oblicuatambién hay pluralidad de liberalidades y se ejecutan todas, eso sí, sucesivamente, ordo sucessivus. Uno es llamado, no en defecto, sino después de otro, si heres erit. La delación a favor del fideicomisario solo tiene lugar después de haberse consumado la delación a favor del fiduciario.

En este sentido, como dice la STS de 29 de diciembre de $1997^{12}$ en su FD Segundo, en la sustitución fideicomisaria hay varios herederos, el primero solo fiduciario, el último sólo fideicomisario, pero los intermedios son fideicomisarios con respecto al anterior y fiduciarios con respecto al posterior. El fideicomisario, tanto el intermedio como el final, siempre es heredero del fideicomitente y nunca del fiduciario. Esto último es importante en el caso que nos ocupa puesto que la voluntad que habrá que indagar es la del testador fideicomitente.

10 Son los llamados hijos puestos en condición y como dice la STSJC de 19 de julio de 1993 (Westlaw Aranzadi RJ/1994/2851) en su FD Segundo «los hijos contemplados «in conditione» lo están en relación con la sustitución, no con la institución; en la sustitución fideicomisaria «sine liberis» la condición opera en relación con la sustitución, a diferencia de una institución condicional (suspensiva o resolutoria) en que la condición actúa respecto de la institución».

11 Luis Roca-Sastre Muncunill, Derecho de sucesiones, Tomo I, Bosch, Barcelona, 1995, págs. 457 y 469.

12 Magistrado ponente: Ilmo. Sr. D. Xavier O'CALlaghan MuÑoz (ROJ 8011/1997). 
Ni que decir tiene que el fideicomiso alcanza, exclusivamente, a los bienes fideicomitidos (los de la testadora fideicomitente) y no a los del fiduciario.

En cuanto a la sustitución fideicomisaria condicional -el fallecimiento con o sin hijos es un acontecimiento posible, futuro e incierto-, tanto en la modalidad si sine liberis decesserit como si cum liberis decesserit, el heredero fiduciario tiene una titularidad sujeta a condición resolutoria y el llamamiento al heredero fideicomisario depende de una condición suspensiva o, mejor dicho, la condición es resolutoria para el fiduciario y suspensiva para el fideicomisario.

La sustitución fideicomisaria condicional si sine liberis decesserit (típico fideicomiso catalán) se sustrae al «relativo ostracismo contemporáneo» al que han pasado las sustituciones fideicomisarias censuradas como desencadenantes de pobreza al sustraer bienes del tráfico económico ${ }^{13}$. Este ostracismo contemporáneo ha dado lugar a que en algunos países europeos las sustituciones fideicomisarias estén prohibidas lo cual puede hacer pensar que se trata de una «institución desconocida», para más de un juez del TEDH ${ }^{14}$.

La doctrina científica ha discutido si los hijos puestos en condición han de ser llamados a la sustitución; en el caso que nos ocupa no hay duda alguna, ya que son llamados expresamente (por eso es también si cum liberis decesserit). Caso de no ser llamados a la sustitución, habiéndolos, el fideicomiso se «purificaría» y el fiduciario podría disponer libremente.

En cuanto a lo anterior, téngase en cuenta que la sustitución fideicomisaria responde a una determinada concepción de la familia y del patrimonio con la finalidad de mantener este patrimonio dentro de ella, algo que en la actualidad (siglo XXI) se conserva no sólo en el Derecho del Principado de Andorra sino también en nuestro Código Civil, en el Derecho catalán, en el navarro y en el balear ${ }^{15}$. Como su-

13 María Fernanda Moretón SANZ, «El llamamiento de los hijos en la sustitución fideicomisaria condicional si sine liberis decceserit: Igualdad en materia sucesoria y prohibición de discriminación por razón de filiación adoptiva», Revista Crítica de Derecho Inmobiliario, núm. 723, 2011, pág. 551.

14 Jesús Delgado EcheverRía, "Autonomía privada y derecho de sucesiones» en Autonomía de la voluntad en el derecho privado: Estudios en conmemoración de la Ley del notariado, Tomo I, Consejo General del Notariado y Wolters Kluwer España, 2012, pág. 534.

15 María del Carmen Gete-Alonso y Calera, «Actos jurídicos transmisivos, negocios patrimoniales y principio de igualdad. Lectura crítica de la Sentencia del Tribunal Europeo de Derechos Humanos de 13 de julio de 2004, caso "Pla et Puncernau versus Andorra”», Revista Crítica de Derecho Privado, núm. 6, 2009, pág. 176. 
braya el Profesor LASARTE Álvarez ${ }^{16}$ y frente a lo ocurrido en Francia en la codificación, donde los sistemas de sustitución fideicomisaria, más o menos puros, fueron extirpados de raíz excluyendo la nota de perpetuidad, en España y por el contrario, fueron mantenidos ya que el gravísimo problema económico de las vinculaciones, mayorazgos y propiedad amortizada se había resuelto mediante la legislación desvinculadora anterior al Código Civil común.

Volviendo al caso de autos, lo que constituye el núcleo de la controversia es si la existencia solo de hijos adoptivos supone el cumplimiento de la condición en la sustitución fideicomisaria si cum liberis decesserit y el consiguiente incumplimiento de la condición en la sustitución fideicomisaria si sine liberis decesserit, o bien, todo lo contrario.

En este sentido, Francesc-Xavier contrajo matrimonio canónico con la demandante Roser Puncernau Pedro. El 11 de noviembre de 1969 el matrimonio adoptó ante notario de A Coruña, en adopción plena, un niño llamado Antoni y, posteriormente, una niña.

El 3 de julio 1995 Francesc-Xavier otorgó un testamento en el cual legaba una cantidad de dinero a su hijo Antoni (primer demandante) y otra a su hija, y nombraba a su esposa Roser (la segunda demandante) heredera universal.

Mediante un codicilo otorgado en la misma fecha, designa fideicomisario en la herencia de su madre a su hijo adoptivo Antoni en nuda propiedad, atribuyendo el usufructo a su esposa Roser. Francesc-Xavier fallece el 12 de noviembre de 1996 y los bienes fideicomitidos fueron adquiridos por su hijo adoptivo y por su viuda.

Por tanto, los herederos potenciales son: Antoni Pla Puncernau, su madre, Roser Puncernau Pedro, y Carolina e Inmaculada Serra Areny, bisnietas de Carolina Puig Oller, la testadora fideicomitente.

Como cuestión previa y antes de emprender el análisis pormenorizado de la resolución, recordaremos que las fuentes del Derecho andorrano son: ley, costumbre y Derecho común. Adicionalmente, hemos de tener en cuenta que el Derecho común, como Derecho supletorio, comprende el Derecho romano, el Derecho canónico y el Derecho catalán.

\section{EL TRIBUNAL DELS BATLLES D'ANDORRA}

El 17 de julio de 1997, Carolina e Inmaculada Serra Areny (hijas del último sustituto vulgar) presentaron ante el Tribunal dels Batlles

16 Carlos Lasarte Álvarez, Derecho de sucesiones. Principios de Derecho civil VII, Marcial Pons, 2011, 7. a ed., págs. 125 y 126. 
d'Andorra (órgano que equivale a nuestros Juzgados de Primera Instancia) una demanda de juicio declarativo en la que solicitaron que se declarase nulo el codicilo otorgado el 3 de julio de 1995 y se condenase a los demandados a restituirles todos los bienes integrantes de la herencia de su bisabuela, así como a satisfacer los daños y perjuicios y las costas.

El Tribunal dels Batlles en sentencia de 14 de octubre de 1999 desestimó las pretensiones de las demandantes. La motivación de la sentencia se basó en las consideraciones siguientes:

- La conformidad de las partes en cuanto a que el contenido del testamento viene fijado por la voluntad del testador en el momento en el que se otorga el testamento y que esta voluntad se ha de deducir de las palabras utilizadas ${ }^{17}$. En el mismo sentido se pronuncia la jurisprudencia.

- Que la testadora estableció una sustitución fideicomisaria de si sine liberis decesserit.

- Que la sustitución fideicomisaria de si sine liberis decesserit tiene como objetivo que el patrimonio se conserve dentro de la familia.

- Que en el momento del otorgamiento del testamento aún no se había promulgado la Constitución ${ }^{18}$ y no existía ninguna ley ordinaria aplicable al caso, con lo cual había que atenerse al Derecho consuetudinario, al ius comune y a la jurisprudencia andorrana ${ }^{19}$.

- Que se deberá tener en cuenta la voluntad de la testadora resultante de las palabras utilizadas y «a la vista de las circumstàncies i la realitat en vigor en el moment de ser expressada».

- Que el Corpus Iuris Civilis asimilaba la palabra «hijo» a los naturales y a los adoptivos; el adoptado rompe todos los lazos con la familia de origen y pasa a integrarse totalmente en la familia del adoptante, asume el nombre de esta familia y, sobre todo, adquiere derechos sucesorios; el hijo adoptivo quedaba equiparado al hijo legítimo ${ }^{20}$. En el mismo sentido la Constitución andorrana ${ }^{21}$.

- Que la adopción tiene como finalidad proporcionar hijos a los que no pueden tenerlos.

\footnotetext{
17 (Digesto 50, 16, 219).

18 La Constitución andorrana fue promulgada el 28 de abril de 1993.

19 Hay que tener en cuenta que el Derecho andorrano era básicamente Derecho consuetudinario y ius comune (Derecho romano y Derecho canónico, fundamentalmente).

20 Diocleciano y Maximiano, Codex 4, 19, 13, 14.

21 La Constitución andorrana en su artículo 13.3 dice que «els fills són iguals davant de la llei, amb independència de la seva filiació».
} 
En consecuencia, el Tribunal dels Batlles declara que no puede entenderse que la testadora quisiera excluir de la herencia a los hijos adoptivos, toda vez que si lo hubiese querido lo hubiera dicho expresamente. Por tanto, el codicilo no puede declararse nulo. Entendemos, como veremos más adelante, que el Tribunal dels Batlles reformula la voluntad de la testadora.

\section{EL TRIBUNAL SUPERIOR DE JUSTÍCIA D'ANDORRA}

La sentencia del Tribunal dels Batlles se recurrió en apelación ante el Tribunal Superior de Justícia d'Andorra por parte de Carolina e Isabel Serra Areny. La sentencia de 18 de mayo de $2000^{22}$ revocó la sentencia recurrida y anuló el codicilo.

Esta sentencia está argumentada y fundamentada del siguiente modo:

- Que la cuestión fundamental estriba en dilucidar si el hijo adoptado en adopción plena se puede considerar como hijo de un matrimonio legítimo y canónico.

- Que el testamento pasa a ser un acto jurídico desde el momento en que se otorga.

- Que en la interpretación del testamento hay que tener en cuenta la situación jurídica del hijo adoptivo en el contexto social y familiar del momento de otorgarse el testamento, es decir, en 1939 o, si se quiere, en 1949, fecha del fallecimiento de la testadora.

- Que tanto de la doctrina como de la jurisprudencia, resulta que la adopción es una institución jurídica prácticamente desconocida en Andorra desde el siglo XIX ya que la finalidad que se perseguía -tener un sucesor- se podía alcanzar con la institución consuetudinaria del heredamiento, con lo cual es bastante improbable que la testadora quisiera incluir a los hijos adoptivos dentro de los hijos habidos de legítimo y canónico matrimonio.

- Que el hijo adoptado por una pareja es un hijo adoptivo y no un hijo legítimo o del matrimonio.

- Que la escritura de adopción se otorgó en España, y con arreglo al Derecho español vigente entonces -Código Civil y Compilación de Derecho Civil Especial de Cataluña- la adopción únicamente creaba un status filii y no un status familiae, con lo cual los hijos

\footnotetext{
22 Magistrado ponente: Sr. D. Lluís PUIG FerRiol.
} 
adoptivos eran personas extrañas jurídica y sociológicamente con relación a los ascendientes del heredero fiduciario.

- Que la sustitución fideicomisaria de si sine liberis decesserit (es el típico fideicomiso familiar catalán) tiene como finalidad mantener el patrimonio familiar dentro de la familia legítima y matrimonial.

- Que la tradición jurídica catalana ha favorecido la exclusión de los hijos adoptivos de este fideicomiso.

- Para que se puedan incluir los hijos adoptivos hace falta la voluntad indubitada de la testadora, que en el presente caso no se ve.

Contra esta sentencia se interpuso recurso de nulidad ante el Tribunal Superior de Justícia d'Andorra fundado en la vulneración del principio de igualdad ante la ley del artículo 6 de la Constitución andorrana, el derecho a la protección judicial y a un proceso equitativo de su artículo 10 . El recurso fue inadmitido a trámite ante la ausencia de fundamento, mediante auto de 28 de junio de 2000.

Teniendo en cuenta que en el sistema judicial del Principado de Andorra no existe recurso de casación, la sentencia del Tribunal Superior de Justícia agota la vía jurisdiccional ordinaria.

\section{EL TRIBUNAL CONSTITUCIONAL D'ANDORRA}

A su vez, fue interpuesto recurso de amparo ante el Tribunal Constitucional d'Andorra ante la alegada violación de los artículos 13.3 (principio de igualdad de los hijos ante la ley con independencia de su filiación) y 10 (derecho a la protección judicial y a un proceso equitativo) de la Constitución andorrana.

El recurso fue inadmitido por las causas que sintetiza la siguiente cita que el auto $^{23}$ hace de las palabras del Ministerio Fiscal:

«la discriminació dels fills adoptius respecte dels biològics, no es derivaria -en aquest cas- d'un acte dels poders públics i, en concret, de la sentència de la Sala Civil del Tribunal Superior, sinó de la voluntat de la testadora o fideïcomitent, que és la que regeix la successió testamentària» ${ }^{24}$.

23 Auto del TC andorrano de 13 de octubre de 2000 (BOPA núm. 60, año 12, 18 de octubre de 2000, págs. 2343 y ss.) (www.bopa.ad). Magistrado ponente: Sr. Joan Josep LóPEz BURNIOL.

24 Traducción: «la discriminación de los hijos adoptivos respecto de los biológicos no derivaría, en este caso, de un acto de los poderes públicos, concretamente de 
Y ello en virtud del principio de libertad de testar como manifestación del principio general de libertad civil ${ }^{25}$. Por otra parte, la interpretación de los actos jurídicos es una cuestión de hecho reservada a la jurisdicción ordinaria.

Contra el auto de inadmisión del recurso a trámite se interpuso un recurso de súplica que fue desestimado ${ }^{26}$.

\section{EL TRIBUNAL EUROPEO DE DERECHOS HUMANOS}

El 16 de mayo de 2001 Antoni Pla Puncernau y Roser Puncernau Pedro interponen ante el TEDH una demanda contra el Principado de Andorra siendo la resolución contra la que se planteó la del Tribunal Superior de Justícia.

Ante el TEDH el Govern d'Andorra alegó que el artículo 8 del CEDH no se podía aplicar dado que no existió "vida familiar», que no existió relación real entre Carolina Pujol Oller y Antoni Pla Puncernau puesto que la primera falleció en 1949 y el segundo fue adoptado en 1969.

Los demandados se oponen a este argumento ya que con ello habrían de ser excluidos los hijos póstumos y que quienes solicitaron la nulidad del codicilo, Carolina e Inmaculada Serra Areny, tampoco conocieron a su bisabuela.

El Tribunal hace una referencia a la sentencia de 13 de junio de $1979^{27}$ (asunto Marckx contra Bélgica) que entendió que los derechos sucesorios entre padres e hijos y entre abuelos y nietos hay que considerarlos bajo el imperio del artículo 8 de la CEDH y que las sucesiones entre parientes próximos están íntimamente asociadas a la vida familiar. El hecho de que la defunción de Carolina Pujol Oller fuera anterior a la adopción de Antoni Pla Puncernau no justifica otra postura por parte del Tribunal, siendo de aplicación el artículo 8 de la CEDH.

Los demandantes afirman que se ha producido una discriminación injustificada en materia de derechos sucesorios basada en el

la sentencia de la sala civil del Tribunal Superior de Justícia, sino de la voluntad de la testadora fideicomitente que rige la sucesión testamentaria».

25 No olvidemos que la libertad civil es uno de los principios interpretativos e integradores del Derecho civil catalán.

26 Por Auto del TC andorrano de 17 de noviembre de 2000 (BOPA núm. 70, año 12, 17 de noviembre de 2000, pág. 2572) (www.bopa.ad).

27 http://hudoc.echr.coe.int/sites/fra/pages/search.aspx?i=001-62092 (fecha de consulta mayo 2013). 
tipo de filiación, con la consiguiente falta de respeto a la vida privada y familiar. Consideran, por tanto, vulnerado el artículo 14 de la CEDH en relación con el artículo 8.

\section{Argumentos de los demandantes}

- Que lo que ahora se plantea no se había planteado antes. El propio Tribunal reconoce que en asuntos precedentes se ventilaban disposiciones legales que suponían una injerencia ilegítima en la vida familiar y/o una discriminación por razón de nacimiento. El caso presente se refiere a la esfera privada, a la autonomía privada.

- Que el caso se debe examinar a la luz del Derecho andorrano vigente en $1996^{28}$ y de la CEDH.

- Que la adopción era una institución conocida y utilizada por la sociedad andorrana en 1939 ya que estaba contemplada tanto por el Derecho romano como por el Derecho canónico.

- Que siguiendo el Derecho romano, cuando una cláusula testamentaria es clara no hay excusa para apartarse con el pretexto de pretender hallar su espíritu.

- Que si la testadora hubiera querido excluir a los hijos adoptivos de la sustitución fideicomisaria, lo hubiera dicho expresamente, como así hacían los notarios andorranos y catalanes cuando esa era la voluntad del otorgante.

Que la cláusula que nos ocupa esta únicamente destinada a descartar a los hijos ilegítimos.

- Que la testadora no hizo distingos por razón de filiación, por tanto, no cabe que los hagan los tribunales máxime cuando es contrario a la Constitución y al CEDH. Por este motivo la sentencia del Tribunal Superior de Justícia supuso una injerencia ilícita en la vida privada y familiar claramente discriminatoria.

En conclusión, los demandantes consideran vulnerados los artículos 8 y 14 del CEDH.

\section{Argumentos del Govern d'Andorra}

La legislación andorrana no discrimina por razón de la filiación.

En el caso que nos ocupa, la discriminación viene por el lado de la libre voluntad de una testadora que, salvo la reserva legal, podía

\footnotetext{
28 La Constitución andorrana de 1993 y la Ley sobre adopción de marzo de 1996.
} 
disponer libremente de sus bienes de conformidad con el Derecho andorrano.

Que ya los postglosadores entendían que la admisión de los hijos adoptivos en el fideicomiso ponía en manos del fiduciario el cumplimiento de la condición con el consiguiente riesgo de fraude o abuso de derecho.

Que el Tribunal Superior de Justícia se limita a decir que la testadora no había llamado a los hijos adoptivos y que «tota crida a una successió testamentària és, per difinició, discriminatòria en el sentit que genera diferències entre els hereus».

Que el Tribunal Superior de Justícia lleva a cabo una interpretación que se corresponde con la voluntad de la testadora expresada en 1939 «a la vista del que era entonces derecho vigente, no porque éste se entendiera aplicable al caso sino porque permitía adivinar cuáles eran los valores sociales de la época que, probablemente, la testadora debía compartir» ${ }^{29}$.

En conclusión, el Govern d'Andorra considera que no ha existido vulneración de las disposiciones invocadas.

\section{Apreciación del Tribunal y crítica de la misma}

El TEDH cita varios litigios a fin de dejar claro que para el Tribunal el artículo $8 \mathrm{CEDH}$ tiende, esencialmente, a proteger al individuo contra las injerencias arbitrarias de los poderes públicos. Estas causas, dice el Tribunal, tenían en común el hecho de que la diferencia de trato procedía de la legislación, en ellas se pretendía constatar si el ordenamiento jurídico vulneraba los derechos de los demandantes ${ }^{30}$.

29 Esther Arroyo i Amayuelas, en Esther Arroyo i Amayuelas y David Bondía García, «¿Interpretación del testamento contraria a los derechos humanos? "El caso 'Pla \& Puncernau vs. Andorra" (STEDH, 13 de julio de 2004)», Derecho Privado y Constitución, núm. 18, 2004, pág. 26.

30 Desde siempre se había entendido que el artículo 8 del CEDH imponía a los Estados firmantes obligaciones negativas. Esto cambió a raíz de la sentencia del TEDH 13 de junio de 1979 (http://hudoc.echr.coe.int/sites/fra/pages/search. aspx?i=001-62092) Marckx contra Bélgica -se trataba de un caso de discriminación en materia de derecho de sucesiones por causa de muerte- al imponer obligaciones positivas al Estado. Ahora bien, tanto en esta sentencia como en otras posteriores sobre de discriminaciones en materia de sucesión intestada, era la ley la que discriminaba. La sentencia del TEDH de 13 de julio de 2004 da un paso más y entra de lleno a controlar, no la legislación de un Estado en materia de sucesión intestada, sino la sucesión testada por la vía de entender que lo que contraría el CEDH no es el poder legislativo sino el poder judicial del Principado de Andorra al interpretar incorrectamente una cláusula testamentaria. 
Entiende el Tribunal que en el caso presente la cuestión que se debate no es la incompatibilidad entre el CEDH y la legislación andorrana, sino la interpretación de una cláusula testamentaria efectuada por el Tribunal Superior de Justícia y confirmada por el Tribunal Constitucional y se trata de averiguar si esta interpretación es contraria a los artículos 8 y 14 del CEDH puestos en relación.

De los textos internacionales resulta que el ámbito de aplicación del principio de igualdad es el público, la proscripción de la desigualdad se dirige principalmente a los poderes públicos, «igualdad ante la ley» (poder legislativo) e «igualdad en la aplicación de la norma jurídica» (poderes judicial y ejecutivo). ${ }^{31}$ En nuestro caso, para el TEDH ha existido una discriminación judicial.

El Tribunal cita varios casos en los que evidencia su criterio consistente en que incumbe a los tribunales nacionales la interpretación y aplicación del derecho interno y que esto mismo, con mayor razón, será de aplicación cuando de lo que se trate es de interpretar un acto eminentemente privado como es una cláusula testamentaria.

«Un problème d'atteinte à la vie privée et familiale ne pourrait donc se poser que dans l'hypothèse d'une appréciation par le juge national des éléments de fait ou de droit interne qui serait manifestement déraisonnable ou arbitraire ou en flagrante contradiction avec les principes fondamentaux de la Convention» $(\$ 46)^{32}$.

«La Cour estime que, contrairement à ce que prétend le Gouvernement, aucune question touchant à la libre volonté de la testatrice n'est en cause; seule l'interprétation de la clause testamentaire entre en ligne de compte» $(\$ 57)^{33}$.

Esta afirmación en palabras de MARSAL GuILlameT ${ }^{34}$, roza el sarcasmo, puesto que difícilmente un tribunal puede interpretar una cláusula testamentaria prescindiendo de la voluntad del testador.

31 María del Carmen Gete-Alonso y Calera, op. cit., pág. 185.

32 Los textos oficiales del Consejo de Europa están en inglés y en francés. Traducción: «un problema de perjuicio a la vida privada y familiar sólo se podría plantear en la hipótesis de una apreciación por parte del juez nacional de los elementos de hecho o de derecho interno que fuera claramente no razonable o arbitraria o en flagrante contradicción con los principios fundamentales de la Convención».

33 Traducción: «El Tribunal entiende, contrariamente a lo que pretende el gobierno, que no se discute ninguna cuestión respecto a la libre voluntad de la testadora; lo único que se toma en consideración es la interpretación de la cláusula testamentaria».

34 Joan Marsal Gullamet, «Els fills posats en condició: Interpretació del testament i discriminació. Comentari a la sentència del Tribunal Europeu de Drets Humans (secció 4. ${ }^{a}$ ) Sentència 13.07.2004 (Pla i Puncernau contra Andorra, núm. 69.498/01)», Revista Jurídica de Catalunya, 2/2005, p. 156. 
«L'interprétation donnée par le Tribunal supérieur de justice de la clause testamentaire consistant à attribuer à la testatrice une volonté négative supposée pour parvenir à la conclusion que, puisque la testatrice n'avait pas expressément dit qu'elle n'excluait pas un fils adoptif c'est qu'elle avait voulu l'exclure, est par trop forcée et contraire au principe général du droit selon lequel si l'énoncé est exempt d'ambiguïté, point n'est besoin de s'interroger sur la volonté de celui qui s'est ainsi exprimé ( «quum in verbis nulla ambiguitas est, non debet admitti voluntatis queastio»)» $(\S 58)^{35}$.

Es decir, como la testadora no ha afirmado que no excluye a los hijos adoptivos, se deduce que los ha querido excluir, o sea el Tribunal Superior de Justicia, según el TEDH, entiende que si la testadora hubiese querido poner a los hijos adoptivos en condición, hubiese tenido que decir expresamente que no los excluía y esto es así porque en el momento de otorgarse el testamento por «hijos de legítimo y canónico matrimonio ${ }^{36}$ no se podían entender incluidos los adoptivos. Con lo cual la interpretación que lleva a cabo el Tribunal Superior de Justícia no es ni forzada ni contraria al principio general que menciona ya que el enunciado, en el momento del otorgarse el testamento, que, por cierto, es el momento sociológico y jurídico que hay que tener en cuenta ${ }^{37}$, está exento de ambigüedad ${ }^{38}$.

35 Traducción: «La interpretación efectuada por el Tribunal Superior de Justicia de la cláusula testamentaria consistente en atribuir a la testadora una supuesta voluntad negativa para llegar a la conclusión de que dado que la testadora no había dicho expresamente que no excluía a un hijo adoptivo es que lo había querido excluir es demasiado forzada y contraria al principio general del derecho según el cual si el enunciado está exento de ambigüedad, no hay ninguna necesidad de preguntarse sobre la voluntad del que así se ha expresado ("quum in verbis nulla ambiguitas est, non debet admitti voluntatis queastio")».

36 La filiación resultante de un matrimonio canónico ha tenido y tal vez aún tenga una especial relevancia en el Principado de Andorra, debido a la vigencia del Derecho canónico y al hecho de que uno de los Co-Príncipes es el obispo de la Seo de Urgel, entre otras razones.

37 «Todas las instancias están de acuerdo -incluso el TEDH- en que el parámetro que debe servir para deducir aquella voluntad es el derecho vigente en el momento de redactar el testamento (año 1939). Otra cosa es que después el TEDH propugne -incorrectamente- la necesidad de "actualizarlo" de acuerdo con la realidad de la época en que se produce la delación del fideicomiso (año 1996)» [ESTHER ARRoyo i AMAYUELAS, op. cit., págs. 34 y 35]. «La cláusula ha de ser examinada en la perspectiva histórica de su consignación, además de que las sustituciones deben regirse por el Derecho vigente a la muerte del causante (fideicomitente), cual enseñan las Sentencias del Tribunal Supremo de 22 diciembre 1973 (RJ 1973/4839) y 30 abril 1981 (RJ 1981/1786)». STSJC, de 19 de julio 1993 FD Segundo (Westlaw Aranzadi $\mathrm{RJ} / 1994 / 2851)$.

38 Refiriéndose a un testamento otorgado en 1934, la STSJC de 19 de julio de 1993 FD Tercero (Westlaw Aranzadi RJ/1994/2851) dice que «ni al tiempo de hacerse el testamento, ni ahora, ni en el concepto jurídico, ni en el vulgar, ni en 
Por el contrario, sí que resulta forzado convertir una hipotética discriminación llevada a cabo por la testadora, en una discriminación materializada por los tribunales al interpretar una cláusula testamentaria.

En el Derecho común se excluía a los hijos adoptivos del fideicomiso y esto obedecía a que así se impedía que la adopción fuese utilizada para defraudar la voluntad del fideicomitente. En particular, en el caso de la sustitución fideicomisaria si sine liberis decesserit, puesto que, de otro modo, el fiduciario podría frustrar las expectativas del fideicomisario a través de la adopción y, recuérdese, que hasta la Constitución (1993) y la ley andorrana de adopción (1996) estuvieron vigentes las normas justinianeas. No se consideraba la adopción como una filiación equiparada a la filiación por naturaleza. En consecuencia, la concepción que tenía la testadora fideicomitente en el momento de otorgar el testamento no podía ser otra que la que imperaba en la época y, por tanto, no hay duda de a qué tipo de filiación se refería en la cláusula que nos ocupa ${ }^{39}$.

Si acudimos a la interpretación literal o gramatical, capital para averiguar la voluntad del testador ${ }^{40}$, lo más razonable es atribuir a las palabras la significación que tienen para el otorgante en el momento del otorgamiento, y ese momento, año 1939, por «hijos y nietos de legítimo y canónico matrimonio» solo se pueden entender los hijos y nietos biológicos habidos en el seno de un matrimonio canónico. Se distinguía entre hijos legítimos, legitimados, naturales, ilegítimos y adoptivos. Los hijos legítimos eran los biológicos habidos como consecuencia de una relación matrimonial. Al tratarse de un testamento notarial hay razones de peso para considerar que la voluntad

\footnotetext{
el social, el vocablo hijo legítimo es extensible a hijo adoptivo [...] no es conveniente separarse (no se debe abandonar) de la significación de las palabras, sino cuando es manifiesto que el testador entendió decir otra cosa (cuando sea evidente que era otra la intención del testador) - «non aliter a significatione verborum recedi oportet, quam quum manifestum est, aliud sensisse testatorem»-, Respuesta de Marcelo, Digesto, libro XXXII, título único, ley 69. Solamente cuando haya oscuridad, duda, ambigüedad, o se aprecie que hay contradicción entre las palabras utilizadas y la intención [SS. 1 febrero 1988 (RJ 1988/581), 5 marzo 1990 (RJ 1990/1667) y 10 junio 1992 (RJ 1992/5119)] se ha de prescindir de la interpretación literal, porque obviamente lo relevante es la voluntad real del testador -art. 675, SS. 9 junio 1987 (RJ 1987/4049), 17 junio 1988 (RJ 1988/5113), 3 noviembre 1989 (RJ 1989/7847), y 30 noviembre 1990 (RJ 1990/9220), entre otras; en que se recoge el principio de honda raigambre histórica de que en los testamentos se interpretan más plenamente las voluntades de los testadores - «in testamentis plenius voluntates testantium interpretantur»-Digesto L, 17, 12, Paulo, "Comentarios a Sabino"».

39 María del Carmen Gete-Alonso y Calera, op. cit., págs. 181 y 182.

40 (Digesto 33, 10, 7-2).
} 
coincide con la literalidad aunque la literalidad de la cláusula tiene serias deficiencias gramaticales y ha precisado una interpretación correctora. A lo que habría que añadir que la adopción apenas se practicaba en el Principado de Andorra.

Reglero Campos ${ }^{41}$ entiende que la voluntad del testador manifestada en el testamento es lo que constituye el objeto de la interpretación y aunque la jurisprudencia admita que el intérprete pueda valerse de medios externos, éstos solo se utilizarán para averiguar cuál era la voluntad del testador en el momento del otorgamiento. En sentido parecido, De la CÁMARA ÁlVAREZ ${ }^{42}$ sostiene que «lo que es inadmisible es que merced al recurso a la prueba extrínseca se constituya una declaración testamentaria inexistente o inconciliable con las que el testamento contiene».

Nuestro TS en su sentencia de 29 de diciembre de $1997^{43}$ FD Tercero no puede ser más lógico y claro cuando dice que:

«con la interpretación del testamento se busca el sentido y alcance de la voluntad del testador. Siendo el testamento un negocio jurídico mortis causa, que se perfecciona con la emisión de voluntad del testador y despliega su eficacia en el momento de la muerte, la voluntad real del testador es la del momento en que emitió su declaración, es decir, de cuando otorgó el testamento; tras este momento, pudo haber cambio de circunstancias, pero el testador siempre puede revocarlo y otorgar nuevo testamento hasta el instante mismo de su muerte. El testamento no puede recoger una voluntad del testador que sea posterior a su otorgamiento; y pensar en su voluntad real, por unos hechos posteriores a la muerte del testador, es ya caer en el absurdo".

Ambulatoria est voluntas defuncti usque ad vitae supremum exitum $^{44}$, en sentido contrario, cuando el testador deje de vivir, su voluntad ya no puede variar.

Lo que suceda después de la declaración de voluntad del testador no importa hasta el punto que la enajenación mental del testador posterior al otorgamiento del testamento no produce la revocación del mismo.

41 Vid, L. Fernando Reglero Campos, Institución de herederos: designaciones erróneas, genéricas e inciertas, Editorial Aranzadi S.A., Pamplona, 1998, pág. 37.

42 Manuel de la Cámara Álvarez, Compendio de sucesiones, Editorial La Ley, Madrid, 1990, pág. 153

43 Magistrado ponente: Ilmo. Sr. D. Xavier O'Callaghan Muñoz (ROJ 8011/1997).

44 (Digesto 34, 4, 4, y Digesto 24, 1, 32, 3). 
En este mismo apartado 58 el TEDH persiste en su error al decir:

«la lecture du testament ne permet pas de déduire que la testatrice souhaitait exclure du bénéfice de la succession un éventuel petitfils adoptif. La Cour conçoit qu'elle aurait pu le faire; puisqu'elle ne l'a pas fait, l'unique conclusion possible et logique est qu'elle n'a pas souhaité le faire ${ }^{45}$.

El TEDH admite que la voluntad de la testadora fideicomitente podría ser perfectamente la de excluir a los hijos adoptivos, «la Cour conçoit qu'elle aurait pu le faire». ¿Y si la testadora hubiera excluido expresamente a los hijos adoptivos? ¿Cuál hubiese sido la respuesta del Tribunal? Esta es la cuestión. Esta es la gran pregunta que queda por responder. Como dice DELGADO ECHEVERRÍA ${ }^{46}$ en esta sentencia late una idea: que la voluntad del testador está limitada por los derechos fundamentales $\mathrm{y}$, en particular, por el principio de no discriminación.

El TEDH dice que la testadora dijo lo que ni dijo ni quiso decir, la suplanta, y todo para adecuar, no de frente sino de soslayo, la cláusula testamentaria al principio de igualdad proclamado en el CEDH. No de frente y sí de soslayo, por medio de una interpretación totalmente arbitraria y ad gustum, puesto que si aceptara los hechos, es decir, que la testadora dijo lo que dijo y no otra cosa, se vería en la tesitura de enfrentarse al hipotético conflicto entre la libertad civil y el principio de igualdad. Mejor hubiese sido declarar ineficaz la disposición testamentaria por violar la $\mathrm{CEDH}$, es decir, utilizar la excepción de orden público.

Ahora bien, como dice Marsal GuIllameT ${ }^{47}$, «si ningú té un dret preferent a ser cridat hereu voluntari d'una persona, les eleccions que lliurement faci el testador no poden generar cap discriminació». Esto no quiere decir, prosigue el autor, que no se pueda producir un conflicto entre la voluntad del testador y un derecho fundamental de la persona libremente elegida por el testador, como, por ejemplo, cualquier condición contraria a los derechos a la dignidad y al libre desarrollo de la personalidad, a la libertad ideológica y religiosa, etc., que al considerarse ilícita, se tendrá por no puesta ${ }^{48}$.

45 Traducción: «la lectura del testamento no permite deducir que la testadora deseaba excluir del beneficio de la sucesión a un eventual nieto adoptivo. El Tribunal entiende que lo podría haber hecho: y puesto que no lo hizo, la única conclusión posible y lógica es que no lo deseó».

46 Vid, op. cit., pág. 534.

47 Op. cit., pág. 159.

48 Ibidem, pág. 160. 
La solución no puede consistir en atribuir a las palabras del testador un significado compatible con el derecho vigente sino en declarar la ineficacia de aquello que sea contrario al orden público ${ }^{49}$, aunque como dice HERRERo OviEDO ${ }^{50}$, siempre cabe la posibilidad de aceptar o no.

No deja de ser llamativo, como advierte Moretón SANz ${ }^{51}$, aunque se refiera a la sentencia 9/2010, de 27 de abril de nuestro Tribunal Constitucional, que nadie haya advertido discriminación por razón de edad y es que como hemos visto en la argumentación del Govern d'Andorra todo llamamiento a una sucesión testamentaria es por lo general discriminatorio sin que ello implique, salvo casos excepcionales, violación del CEDH, eso claro, si queremos mantener la sucesión testada.

«Certes, la Cour n'est pas appelée, en principe, à régler des différends purement privés. Cela étant, dans l'exercice du contrôle européen qui lui incombe, elle ne saurait rester inerte lorsque l'interprétation faite par une juridiction nationale d'un acte juridique, qu'il s'agisse d'une clause testamentaire, d'un contrat privé, d'un document public, d'une disposition légale ou encore d'une pratique administrative, apparaît comme étant déraisonnable, arbitraire ou, comme en l'espèce, en flagrante contradiction avec l'interdiction de discrimination établie à l'article 14 et plus largement avec les principes sous-jacents à la Convention (Larkos c. Chypre [GC], no 29515/95, §§30-31, CEDH 1999-I)» (§59) ${ }^{52}$.

Como podemos apreciar, el TEDH va más allá de la interpretación de las cláusulas testamentarias, ya que se está refiriendo a los contratos privados y no menciona el tiempo transcurrido desde el otorgamiento como sí hace más adelante en el §62. Es decir, estos criterios no solo afectarán a la autonomía privada

$49 \quad$ Ibídem, pág. 162.

$50 \mathrm{Vid}$, «El testamento, la filiación adoptiva y la aplicación inter privatos de los Derechos Fundamentales», InDret, 2/2012, pág. 28.

51 María Fernanda Moretón SANZ, op. cit., pág. 566.

52 Traducción: «Es cierto que, en principio, al Tribunal no se le pide que resuelva controversias puramente privadas. Dicho esto, en el ejercicio del control europeo que le incumbe, no puede permanecer pasivo cuando la interpretación efectuada por una jurisdicción nacional de un acto jurídico, tanto si se trata de una cláusula testamentaria, de un contrato privado, de un documento público, de una disposición legal e incluso de una práctica administrativa aparezca como no razonable, arbitraria o, como en este caso, en flagrante contradicción con la prohibición de discriminación establecida en el artículo 14 y más ampliamente con los principios subyacentes de la Convención (Larkos c. Chypre [GC], no 29515/95, §§ 30-31, CEDH 1999-I)». 
en el ámbito de la libertad de testar sino en el ámbito de todo el Derecho privado. Con todo, nos encontramos ante un obiter dicta que como tal tiene un indudable efecto persuasivo pero no decisivo como, por el contrario, sí ostenta la ratio decidendi.

Insiste el TEDH en el §59 cuando dice que en el ejercicio del control que le compete no puede quedar impasible ante una cláusula testamentaria que parezca que no es razonable, arbitraria o, como en el caso que nos ocupa, se halla en flagrante contradicción con el principio de no discriminación del artículo 14. Estamos en lo mismo, o respetamos la voluntad de la testadora o la sustituimos por la voluntad del Tribunal, lo que no se puede hacer es reelaborar la voluntad de la testadora por mucho que se tenga puesta la vista en el artículo 14 del CEDH, puesto que al liquidar la voluntad de la testadora se liquidaría la esencia misma del testamento, de la sucesión voluntaria.

«Ainsi, à supposer même que la clause testamentaire en question eût nécessité une interprétation par les juridictions internes, une telle interprétation ne pouvait se faire exclusivement à la lumière du contexte social en vigueur au moment de la rédaction du testament ou du décès de la testatrice, en l'occurrence en 1939 et en 1949, dans la mesure où, notamment, une période de cinquante-sept ans s'est écoulée entre la date d'établissement du testament et le moment de l'ouverture de la succession. En présence d'un intervalle de temps aussi long, au cours duquel de profonds changements sont survenus dans les domaines tant social qu'économique et juridique, le juge ne peut ignorer ces nouvelles réalités» $(\S 62)^{53}$.

Como dice MEDINA ORTIZ ${ }^{54}$ «la regla introducida por esta sentencia podría resumirse en el siguiente sentido: En la interpretación de disposiciones testamentarias, el intérprete no puede limitarse a

53 Traducción: «Así, incluso si suponemos que la cláusula testamentaria en cuestión hubiese requerido una interpretación por parte de las jurisdicciones internas, esta interpretación no podría hacerse exclusivamente a la luz del contexto social en vigor en el momento de la redacción del testamento o del fallecimiento de la testadora, ocurridos en 1939 y en 1949, en la medida que, especialmente, ha transcurrido un período de cincuenta y siete años entre la fecha del otorgamiento del testamento y el momento de la apertura de la sucesión. En presencia de un intervalo de tiempo tan largo, durante el cual se han producido profundos cambios en los ámbitos tanto social como económico y jurídico, el juez no puede ignorar estas nuevas realidades».

54 Jordi Medina OrTiz, «Nuevo criterio en la interpretación de las disposiciones testamentarias introducido por el TEDH», La Notaría, 10/2004, pág. 64. Jordi Medina Ortiz ha sido uno de los abogados del gobierno del Principado de Andorra en este pleito. 
investigar cuál fue la voluntad del testador al tiempo de hacer testamento o al tiempo de su fallecimiento, sino que también debe tener en cuenta la realidad social, jurídica y económica del momento en que deba surtir efecto la disposición testamentaria». Por tanto, se separa, en materia de interpretación de las disposiciones testamentarias, tanto de los criterios sostenidos por nuestro Tribunal Supremo como de las reglas del artículo 675 del Código Civil.

Sigue diciendo el citado autor que «la regla básica en la interpretación de disposiciones testamentarias ha sido, desde el Derecho Romano, la búsqueda de cuál fue la voluntad del testador. La voluntad del testador fue calificada como 'ley' de la sucesión. Y esta voluntad se ha de interpretar según las palabras empleadas por el testador en su testamento (Digesto 33.10.7.2; 35.1.19; 50, 17,12-33,8, 6,3 y 32, 25,1. Codex 6.37.23.2. ${ }^{\mathrm{a}}$, Instituta 2.20.2) ${ }^{55}$.

La voluntad del testador como «ley» de la sucesión es algo que la doctrina científica no ha cuestionado.

El TEDH hace decir a la testadora algo que no dice y así consigue dos objetivos, uno, no separarse formalmente del criterio doctrinal de la voluntad del testador como «ley» de la sucesión; otro, adecuar la cláusula testamentaria al CEDH.

De ahí que como dice MEDINA ORTIZ ${ }^{56}$ «cualquier autoridad del Estado, cuando tenga que prestar su actividad en relación con alguna relación jurídica, aunque sea entre particulares, deberá hacerlo de forma que impida la vulneración de los derechos reconocidos a los particulares en la CEDH», aunque esta opinión habría que matizarla y puntualizarla mucho.

Ahora bien, siguiendo a BoNDIA GARCIA ${ }^{57}$, el TEDH constata la existencia de una discriminación con respecto a un derecho (el derecho a la herencia) que ni siquiera de forma implícita está reconocido en el $\mathrm{CEDH}^{58}$.

\footnotetext{
55 Op.cit., pág. 73.

56 Ibidem, pág. 68.

57 David Bondía García en Esther Arroyo i Amayuelas y David Bondía García, "¿Intepretación del testamento contraria a los derechos humanos? 'El caso 'Pla \& Puncernau vs. Andorra' (STEDH, 13 de julio de 2004)», Derecho Privado y Constitución, núm. 18, 2004, pág. 70.

58 «Nadie tiene derecho a recibir una liberalidad. El testador ejerce un poder privado, no un officium o una función (como "padre de familia»). Puede comportarse libremente, arbitrariamente, incluso caprichosamente, conforme a sus criterios y valoraciones personales. No está sujeto-legalmente- a principios de justicia o equidad en el «reparto» de sus bienes» (JESÚs DELGADo EcheVERRÍA, op. cit., pág. 536). Eso sí, hay que dejar a salvo la legítima.
} 
En virtud de los argumentos antes recogidos, el Tribunal entiende, por cinco votos contra dos, que ha existido vulneración del artículo 14 en combinación con el artículo 8 de la CEDH.

\section{Votos disidentes}

El del Juez Sir Nicolás Bratza: «Le fait qu'au regard de la Convention toute discrimination entre individus (moyennant par exemple l'établissement de distinctions fondées sur les liens biologiques ou adoptifs entre enfants et parents dans l'exercice des droits successoraux) soit interdite aux organes législatifs ou judiciaires de l'Etat ne signifie pas que l'on empêche de la même façon les particuliers d'opérer une discrimination en faisant de pareilles distinctions dans la transmission de leurs biens. En principe, il doit être loisible à un testateur, dans l'exercice de son droit de propriété, de choisir à qui il lègue ses biens et, par le contenu de son testament, de faire la différence entre ses héritiers potentiels, notamment en distinguant entre, d'une part, enfants et petits-enfants biologiques et, d'autre part, enfants et petits-enfants adoptifs» $(\S 4)^{59}$.

También disiente de la mayoría que considera que la voluntad de la testadora no se debía interpretar teniendo en cuenta las condiciones sociales y jurídicas del momento del otorgamiento.

El juez Garliki entiende que el CEDH, en este caso, no tiene eficacia directa entre particulares, es decir, considera que no cabe la eficacia horizontal o entre particulares de los derechos fundamentales, la unmittelhere drittwirkung, opinión coincidente con la del juez Nicolás Bratza, aunque deja abierta la posibilidad de que en otros casos se pueda privar de eficacia a cláusulas contrarias al CEDH. Dice que de la jurisprudencia del TEDH resulta que el Estado puede estar obligado a adoptar medidas relativas al respeto de los derechos garantizados en el CEDH en las relaciones de los particulares entre sí. Cita casos como el derecho de asociación (Young, James y Webster c. Reino Unido, sentencia de 13 agosto 1981, serie A n. ${ }^{\circ} 44$, primera

59 Traducción: «El hecho de que a la vista de la Convención toda discriminación entre individuos (mediante, por ejemplo, el establecimiento de distinciones fundadas sobre los lazos biológicos o adoptivos entre hijos y padres en el ejercicio de los derechos sucesorios) está prohibida a los órganos legislativos o judiciales del Estado no significa que se impida de la misma manera a los particulares efectuar una discriminación haciendo iguales distinciones en la transmisión de sus bienes. En principio, debe estar permitido a un testador, en el ejercicio de su derecho de propiedad, elegir a quien lega sus bienes y, por el contenido del testamento, establecer diferencias entre los potenciales herederos, especialmente distinguiendo entre, de una parte, los hijos biológicos y, de otra, los hijos adoptivos». 
sentencia en esta línea) y el derecho de reunión (Plattform «Ärzte für das Leben» c. Austria, sentencia de 21 junio 1988, serie A n. ${ }^{\circ} 139$ ), entre otros.

«Néanmoins, il semble tout aussi évident que le niveau de protection contre un acte privé ne saurait être équivalent au niveau de protection contre un acte de l'Etat. Le simple fait qu'au regard de la Convention il puisse être interdit à l'Etat de prendre certaines mesures (comme l'introduction en matière successorale de distinctions entre les enfants -les arrêts Marckx c. Belgique, 13 juin 1979, série A no 31; Vermeire c. Belgique, 29 novembre 1991, série A no 214-C; Mazurek c. France, no 34406/97, CEDH 2000-II)- ne signifie pas que l'on empêche de la même façon les particuliers de prendre de telles mesures. En d'autres termes, ce qui est interdit à l'Etat n'a pas forcément à l'être aussi aux individus ${ }^{60}$.

Entiende que la idea misma del testamento implica una derogación del régimen de la sucesión intestada, es decir, implica discriminaciones entre los potenciales herederos y que la libertad que tiene el testador se encuentra protegida por el artículo 8 del CEDH y por el artículo 1 del protocolo n. ${ }^{\circ} 1$.

Añade que hay que dar eficacia a las cláusulas testamentarias salvo circunstancias excepcionales en las que la cláusula pueda resultar incompatible con el CEDH. Estas circunstancias excepcionales no se dan en el asunto Pla y Puncernau c Andorra.

\section{Efectividad interna de la sentencia}

En el título II del CEDH se crea el TEDH con el objetivo de controlar el cumplimiento por parte de los Estados firmantes, en relación con sus ciudadanos, del $\mathrm{CEDH}^{61}$. El ciudadano que se considere perjudicado, podrá demandar al Estado al cual pertenece y éste po-

${ }^{60}$ Traducción: «No obstante, parece también evidente que el nivel de protección contra un acto privado no puede ser equivalente al nivel de protección contra un acto del Estado. El simple hecho de que a la vista del la Convención pueda estar prohibido al Estado tomas ciertas medidas (como la introducción de diferencias entre los hijos en materia sucesoria -sentencias Marckx c. Bélgica, 13 junio 1979, serie A n. ${ }^{\circ}$ 31; Vermeire c. Bélgica, 29 noviembre 1991, serie A n. ${ }^{\circ}$ 214C; Mazurek c. Francia, n. ${ }^{\circ}$ 34406/97, CEDH 2000-II)- no significa que se impida del mismo modo a los particulares adoptar tales medidas. En otros términos, aquello que está prohibido al Estado no tiene por qué estar prohibido forzosamente también a los particulares».

61 Como ya dejó claro la desaparecida Comisión Europea de Derechos Humanos, en su Decisión de 10 de julio de 1978 (Caso Chipre contra Turquía), «las obligaciones derivadas del Convenio son obligaciones objetivas que una Alta Parte 
drá ser condenado a indemnizar al ciudadano y también a adoptar medidas para que la violación del CEDH no se vuelva a producir.

Nos hemos de plantear qué influencia debe tener una sentencia del TEDH sobre los Estados firmantes del CEDH, concretamente sobre España, según estemos hablando de un caso en el que España haya sido parte o de otro en el que no haya sido parte, como es el asunto Pla y Puncernau contra Andorra que ahora estamos analizando.

El primero de los supuestos, aunque no sea el que nos ocupa, tiene su interés para los hipotéticos casos en los que España pudiera ser parte y se planteara un conflicto entre la autonomía privada y el principio de igualdad.

Teniendo en cuenta que para un Estado que haya sido parte según el artículo 35.1 CEDH no podrá recurrirse al TEDH sino después de agotar las vías internas, es decir, la vía jurisdiccional, en nuestro ordenamiento jurídico, en principio, una resolución firme y definitiva no podría verse afectada por una sentencia del $\mathrm{TEDH}^{62}$ y la sanción consistirá en una indemnización al perjudicado a cargo del Estado.

Nuestro $\mathrm{TS}^{63}$ entiende que las sentencias del TEDH tienen simplemente naturaleza declarativa, que nuestro Ordenamiento Jurídico

contratante asume con respecto a las personas dependientes de su jurisdicción y no cara a las otras partes contratantes».

62 Según el artículo 18.1 LOPJ «las resoluciones judiciales sólo podrán dejarse sin efecto en virtud de los recursos previstos en las leyes». Algunos Estados como Luxemburgo, Noruega, Malta, algunos cantones suizos, Austria y Bélgica, tienen prevista la revisión de sentencias definitivas internas cuando exista una sentencia del TEDH que declare que ha existido violación del CEDH (véase INÉs ARRIAGA IRABURU, El derecho a la vida familiar de los extranjeros en la jurisprudencia de Estrasburgo, Eunsa, Pamplona, 2003, p.73, nota 191).

${ }^{63}$ La STS de 20 de noviembre de 1996 (Magistrado ponente: Ilmo. Sr. D. Ignacio Sierra GIL DE LA Cuesta) (ROJ 6502/1996) en su FD Primero dice que "Las resoluciones definitivas [...] dictadas por el Tribunal Europeo de Derecho Humanos [...] sólo tienen naturaleza declarativa, según se infiere, no solo, del artículo 50 del Convenio Europeo de Salvaguarda de Derechos Humanos y Libertades Fundamentales ( El Convenio»), sino también de pacífica y consolidada jurisprudencia de dicho T.E.D.H., como son las emblemáticas resoluciones de 25 de abril de 1983 (Caso Pakelli) y de 24 de febrero de 1984 (Caso Digeon), que establecen que el Convenio no atribuye competencia al Tribunal, ni para anular la sentencia, ni para ordenar la desautorización de los temas objeto de la queja. En relación y como consecuencia de lo anterior, en referencia a la presente cuestión, hay que destacar que las resoluciones del T.E.D.H. no tienen efecto directo o de ejecución en el sistema judicial español. Para corroborar lo anterior, se debe afirmar que el ordenamiento judicial español no prevé la ejecución de sentencias internacionales -no confundir con sentencias dictadas por Tribunales extranjeros, cuya ejecución puede llevarse a cabo por Tribunales españoles-. Pero es que, además, el T.E.D.H. no es un órgano judicial supranacional; pues el reconocimiento del Estado Español 
no tiene prevista la ejecución de sentencias dictadas por tribunales internacionales y que no es posible dar al TEDH la naturaleza de última instancia judicial ya que el TEDH no forma parte de la organización judicial española, de conformidad con el artículo 117 de la Constitución ${ }^{64}$. Aunque esto podría ser puesto en tela de juicio

de la jurisdicción de dicho Tribunal, no puede exceder a lo previsto en el artículo 46 del Convenio, que colateralmente prohíbe dar naturaleza de Tribunal nacional de última instancia definitiva al Tribunal de Estrasburgo. Sobre todo porque el artículo 117-3 de la Constitución Española, establece que el ejercicio de la potestad jurisdiccional de todo tipo de procesos, juzgando y haciendo ejecutar lo juzgado, corresponde exclusivamente a los Juzgados y Tribunales españoles determinados por las leyes. Y, hoy por hoy, introducir el T.E.D.H. en la organización judicial española, solo sería factible a través de una «lex data» de naturaleza orgánica, a tenor de lo dispuesto en el artículo 81-1 de la Constitución de España». Y en el FD Segundo dice: «Todo lo anterior lleva inexorablemente a la conclusión de la no posibilidad de producir efectos anulatorios las sentencias tanto del T.E.D.H., como de las decisiones del comité de Ministros, en el ordenamiento jurídico español, pues para que ello fuera posible tendrían que utilizarse los siguientes caminos: a) Modificar la legalidad actual, como han hecho los Estados de Noruega, Luxemburgo, Malta y el cantón suizo de Appenzell, estableciendo un nuevo motivo de revisión de sentencias firmes, o b) La firma de un nuevo protocolo de Convenio, que estableciera un procedimiento para el cumplimiento de las resoluciones de T.E.D.H. o las decisiones del Comité de Ministros, por los Estados demandados».

64 JORDI BONET PÉREZ, «El problema de la efectividad interna de las sentencias del Tribunal Europeo de Derechos Humanos», Revista Jurídica de Catalunya, 1/1993, págs. 61 y 62. La STC 245/1991, de 16 de diciembre (Magistrado ponente: Miguel RoDRÍGUEZ-PIÑEDO Y BRAVO-FERRER) en su FJ 2. ${ }^{\circ}$ dice: «El reconocimiento por España de la competencia de la Comisión Europea para conocer de las demandas sobre la violación de los derechos humanos, de conformidad a lo dispuesto en el art. 25 del Convenio, y la aceptación como obligatoria de la jurisdicción del TEDH no suponen, sin embargo, que las Sentencias de este Tribunal tengan eficacia ejecutiva, pues de la propia regulación del Convenio, y de su interpretación por el Tribunal Europeo, se deriva que las resoluciones del Tribunal tienen carácter declarativo y no anulan ni modifican por sí mismas los actos, en este caso Sentencias, declarados contrarios al Convenio. Así en el caso MARCKX (Sentencia de 13 de junio de 1979), el Tribunal Europeo ha afirmado que «la Sentencia del Tribunal es esencialmente declarativa y deja al Estado la decisión de los medios a utilizar en su ordenamiento jurídico interno para adaptarse a lo que le impone el art. 53» (parágrafo 58). O, lo que es lo mismo, «el Convenio no le atribuye al Tribunal competencia ni para anular la Sentencia del Tribunal nacional ni para ordenar al Gobierno que desautorice los pasajes objeto de la queja» (PAKELLI, 25 de abril de 1983, parágrafo 55). Desde la perspectiva del Derecho Internacional y de su fuerza vinculante (art. 96 C.E.), el Convenio ni ha introducido en el orden jurídico interno una instancia superior supranacional en el sentido técnico del término, de revisión o control directo de las decisiones judiciales o administrativas internas, ni tampoco impone a los Estados miembros unas medidas procesales concretas de carácter anulatorio o rescisorio para asegurar la reparación de la violación del Convenio declarada por el Tribunal (o, en su caso, por el Comité de Ministros de acuerdo al art. 32 del Convenio). El Convenio no obliga a los Estados miembros a eliminar las consecuencias del acto contrario a la obligación jurídica internacional asumida por el Estado, restableciendo en lo posible la situación anterior a ese acto, antes bien el art. 50 permite sustituir por una satisfacción equitativa ese restablecimiento que 
atendiendo al artículo 2.1 LOPJ cuando dice que «El ejercicio de la potestad jurisdiccional, juzgando y haciendo ejecutar lo juzgado, corresponde exclusivamente a los Juzgados y Tribunales determinados en las leyes y en los tratados internacionales».

La vía jurisdiccional ordinaria a través de los recursos de nulidad y revisión no nos conducen a ninguna parte, en el primer caso, porque se dirigiría contra una resolución firme (artículo 240.2 LOPJ), y en el segundo, porque no encajaría en ninguno de los motivos tasados. Solo nos queda la vía constitucional a través del recurso de amparo para declarar la nulidad de la sentencia firme, lo que ocurre es que el CEDH exige que se agoten los recursos internos y por tanto el Tribunal Constitucional ya se habría pronunciado.

Según el artículo 46.1 del CEDH «las Altas Partes Contratantes se comprometen a acatar las sentencias definitivas del Tribunal en los litigios en los que sean partes». Es decir, para los Estados que sean parte son obligatorias y jurídicamente vinculantes, pero, por otro lado, «el Tribunal Europeo no tiene atribuciones para anular o modificar los actos legislativos, ejecutivos o jurisdiccionales internos que hayan dado lugar a la contradicción ${ }^{65}$.

En conclusión, las sentencias del TEDH vinculan al Estado español pero carecen de fuerza ejecutiva directa. El propio Tribunal Constitucional en su sentencia 245/91, de 16 de diciembre ${ }^{66}$ ha pedido que se habiliten cauces en la jurisdicción ordinaria ${ }^{67}$.

pone en cuestión el carácter definitivo y ejecutorio de la decisión judicial interna, si bien tal satisfacción equitativa sustitutoria sólo entra en juego cuando el derecho interno no permite la reparación perfecta de las consecuencias de la resolución o Sentencia estatal. Según la opinión absolutamente dominante, el Convenio no obliga a dar efecto interno a las Sentencias del Tribunal Europeo mediante la anulación de la autoridad de cosa juzgada y de la fuerza ejecutoria de la decisión judicial nacional que dicho Tribunal haya estimado contraria al Convenio. Tampoco el art. 13 del Convenio confiere al justiciable un derecho para ampliar los motivos previstos en el derecho interno para la reapertura del procedimiento judicial que ha dado lugar a una Sentencia firme y ejecutoria». Hay que precisar que el artículo $50 \mathrm{CEDH}$ pasó a ser el artículo 41 (en virtud de la reforma operada por el Protocolo núm. 11, de 11 mayo 1994). La sentencia del TEDH de 24 de abril de 1983, caso Pakelli contra Alemania, dice con respecto al Tribunal que «la Convention ne lui attribue compétence ni pour annuler l'arrêt de la Cour fédérale ni pour ordonner au Gouvernement de désavouer les extraits incriminés (voir, mutatis mutandis, les arrêts Marckx du 13 juin 1979, série A no 31, pág. 25, par. 58, et Dudgeon du 24 février 1983, série A no 59, pág. 8, par. 15)» § 45 http://hudoc.echr.coe. int/sites/fra/pages/search.aspx?i=001-62112 (fecha de consulta mayo 2013).

65 Ibídem, pág. 63.

66 (BOE núm. 13, 15 de enero de 1992).

67 FJ 5. ${ }^{\circ}$ : «para coordinar adecuadamente la tutela del derecho reconocido en el Convenio y la tutela del derecho fundamental reconocida en la Constitución, el Poder legislativo debería establecer cauces procesales adecuados a través de 
¿Cómo se puede dar efectividad interna a una sentencia del TEDH en un pleito en el que España no ha sido parte?

No cabe ninguna duda que el CEDH forma parte de nuestro Ordenamiento Jurídico de conformidad con el artículo $96 \mathrm{CE}^{68}$ con lo cual y según el artículo 9.1 CE los poderes públicos quedan vinculados al mismo y a la jurisdicción que en él se establece. A mayor abundamiento y con arreglo al artículo 10.1, las normas relativas a los derechos fundamentales y a las libertades que la Constitución reconoce se interpretarán de conformidad con los tratados y acuerdos internacionales ratificados por España. Por todo ello, la sentencia del caso Pla y Puncernau contra Andorra vincula a nuestros poderes públicos, legislativo, ejecutivo y judicial, lo que no quiere decir que el TEDH tenga el carácter de órgano judicial supranacional ni que sus sentencias tengan fuerza ejecutiva directa.

Llegados aquí y habida cuenta de que nuestros notarios son a la vez funcionarios públicos y profesionales del Derecho también nos podemos plantear hasta qué punto un notario debe o puede negarse a autorizar un testamento en el que se discrimine a una determinada categoría de hijos ${ }^{69}$. Claro que, como generalmente la sucesión testada conlleva algún tipo de discriminación, resultará que un notario no puede autorizar testamentos que, por ejemplo, no igualen a todos los hijos. Conclusión a todas luces absurda. Sería un torpedo contra la línea de flotación de la sucesión testada.

En el caso de la sentencia TEDH de 13 de julio de 2004, los demandantes entienden que la reparación debería consistir en la revocación de la sentencia del Tribunal Superior de Justícia y la confirmación de la sentencia del Tribunal de Batlles y el reconocimiento

\footnotetext{
los cuales sea posible articular, ante los órganos del Poder Judicial, la eficacia de las resoluciones del TEDH en aquellos supuestos en los que, como ocurre en el presente caso, se haya declarado la infracción de derechos fundamentales [...] En tanto que tales reformas no se establezcan, este Tribunal no puede sustraerse de conocer [...] dado que se trata de un derecho fundamental protegible en amparo». Como dice en su voto particular el Magistrado Ilmo. Sr. D. Vicente Gimeno Sendra en el motivo de discrepancia quinto, se produce una vulneración de la cosa juzgada puesto que el asunto ya fue objeto de conocimiento por parte de este Tribunal mediante una resolución desestimatoria (ATC 173/1983). El Comité de Ministros en su Recomendación R. (2000) 2 de 19 de enero de 2000 sobre el reexamen o reapertura de ciertos casos en el plano interno como consecuencia de sentencias del TEDH, exhorta a los Estados parte a adoptar mecanismos adecuados para la revisión de los procesos internos en el caso de sentencias contrarias al CEDH.

68 El CEDH fue ratificado por España el 26 de septiembre de 1979, entrando en vigor para nuestro país el 4 de octubre de ese mismo año, fecha del depósito de su Instrumento de Ratificación (BOE núm. 243, de 10 de octubre de 1979).

69 Jordi Medina OrTiz, op. cit., pág. 84.
} 
del primer demandado como heredero fideicomisario de su abuela Carolina Pujol Oller (§66). Sin embargo y debido a que Andorra carece de mecanismo hábil para hacer efectiva y ejecutiva la STEDH, las hermanas Carolina e Inmaculada Serra Areny continuarán siendo las herederas del fideicomiso y el gobierno andorrano deberá indemnizar con arreglo al artículo $41 \mathrm{CEDH}$ a los demandantes.

\section{BIBLIOGRAFÍA}

ARRIAGA IRABURU, Inés, El derecho a la vida familiar de los extranjeros en la jurisprudencia de Estrasburgo, Eunsa, Pamplona, 2003.

ARROYO I AMAYUELAS, Esther y BONDÍA GARCÍA, David, «¿Interpretación del testamento contraria a los derechos humanos? El caso Pla \& Puncernau vs. Andorra (STEDH de 13 de julio de 2004)», Derecho Privado y Constitución, núm. 18, 2004.

BONET PÉREZ, Jordi, «El problema de la efectividad interna de las sentencias del Tribunal Europeo de Derechos Humanos», Revista Jurídica de Catalunya, 1/1993.

BORRELL Y SOLER, Antonio María, Derecho civil vigente en Cataluña, I, Barcelona, 1944.

DE LA CÁMARA ÁLVAREZ, Manuel, Compendio de sucesiones, Editorial La Ley, Madrid, 1990.

DELGADO ECHEVERRÍA, Jesús, «Autonomía privada y derecho de sucesiones» en Autonomía de la voluntad en el derecho privado: Estudios en conmemoración de la Ley del notariado, Tomo I, Consejo General del Notariado y Wolters Kluwer España, 2012.

GETE-ALONSO Y CALERA, María del Carmen, «Actos jurídicos transmisivos, negocios patrimoniales y principio de igualdad. Lectura crítica de la sentencia del Tribunal Europeo de Derechos Humanos de 13 de julio de 2004, caso "Pla et Puncernau versus Andorra"», Revista Crítica de Derecho Privado, núm. 6, 2009.

HERRERO OVIEDO, Margarita, «El testamento, la filiación adoptiva y la aplicación inter privatos de los Derechos Fundamentales», InDret, 2/2012. http://www.indret.com/pdf/889_es.pdf

LASARTE ÁlVAREZ, Carlos, Derecho de sucesiones. Principios de Derecho civil VII, Marcial Pons, Madrid, 2011, 7. . ed.

MARSAL GUILLAMET, Joan, «Els fills posats en condició: interpretació del testament i discriminació. Comentari a la sentència 
del Tribunal Europeu de Drets Humans (Secció 4. ${ }^{a}$ ) Sentència 13.7.2004 (Pla i Puncernau contra Andorra, núm. 69.498/01», Revista Jurídica de Catalunya, 2/2005.

MEDINA ORTIZ, Jordi, «Nuevo criterio en la interpretación de las disposiciones testamentarias, introducido por el TEDH», $\mathrm{La} \mathrm{No}$ taria, 10/2004.

MORETÓN SANZ, María Fernanda, «El llamamiento de los hijos en la sustitución fideicomisaria condicional si sine liberis decceserit: igualdad en materia sucesoria y prohibición de discriminación por razón de filiación adoptiva», Revista Crítica de Derecho Inmobiliario, núm. 723, enero 2011.

PUIG FERRIOL, LLUÍS / Roca Trías, Institucions del Dret Civil de Catalunya, Bosch, Barcelona, 1984.

REGLERO CAMPOS, L. Fernando, Institución de herederos: designaciones erróneas, genéricas e inciertas, Editorial Aranzadi S.A., Pamplona, 1998.

ROCA-SASTRE MUNCUNILL, Luis, Derecho de sucesiones, tomo I, Bosch, Barcelona, 1995.

TORRALBA MENDIOLA, E. «Sobre la eficacia en España de las resoluciones del Tribunal Europeo de Derechos Humanos», Derecho Privado y Constitución, n. ${ }^{\circ}$ 21, 2007.

\section{VIII. ÍNDICE DE RESOLUCIONES JUDICIALES CITADAS}

\section{Tribunal Europeo de Derechos Humanos}

Sentencia de 13 de junio de 1979

Sentencia de 24 de abril de 1983

Sentencia de 13 de julio de 2004

\section{Tribunal Constitucional D'Andorra}

Auto de 13 de octubre de 2000

Auto de 17 de noviembre de 2000

\section{Tribunal Superior de Justícia d'Andorra}

Sentencia de 18 de mayo de 2000

Auto de 28 de junio de 2000 


\section{Tribunal dels Batlles d'Andorra}

Sentencia de 14 de octubre de 1999

\section{Tribunal Constitucional Español}

Sentencia de 16 de diciembre de 1991

Sentencia de 27 de abril de 2010

\section{Tribunal Supremo}

Sentencia de 20 de noviembre de 1996

Sentencia de 29 de diciembre de 1997

\section{Tribunal Superior de Justicia de Cataluña}

Sentencia de 19 de julio de 1993 